\title{
PENINGKATAN PENGETAHUAN MASYARAKAT KELURAHAN RUMBAI BUKIT KECAMATAN RUMBAI KOTA PEKANBARU MENGENAI PENYELESAIAN SENGKETA JUAL BELI TANAH BERDASARKAN KITAB UNDANG-UNDANG HUKUM PERDATA
}

\author{
Suhendro'), Andrew Shandy Utama ${ }^{2)}$, Ade Pratiwi Susanty ${ }^{3)}$ \\ 1)Fakultas Hukum Universitas Lancang Kuning \\ Email: andrew.fh.unilak@gmail.com
}

\begin{abstract}
ABSTRAK
Permasalahan mitra dalam kegiatan pengabdian kepada masyarakat ini adalah minimnya pengetahuan masyarakat Kelurahan Rumbai Bukit Kecamatan Rumbai Kota Pekanbaru mengenai penyelesaian sengketa jual beli tanah berdasarkan Kitab Undang-Undang Hukum Perdata. Solusi yang ditawarkan dalam kegiatan pengabdian kepada masyarakat ini adalah peningkatan pengetahuan masyarakat Kelurahan Rumbai Bukit Kecamatan Rumbai Kota Pekanbaru mengenai penyelesaian sengketa jual beli tanah berdasarkan Kitab Undang-Undang Hukum Perdata. Metode pelaksanaan yang digunakan dalam kegiatan pengabdian kepada masyarakat ini adalah dengan menggunakan metode ceramah, dialog, dan diskusi dalam rangka memberikan penyuluhan hukum kepada masyarakat. Partisipasi mitra dalam kegiatan pengabdian kepada masyarakat ini adalah dengan menyediakan waktu, menyediakan tempat beserta fasilitas pendukungnya, dan menghadirkan masyarakat sebagai peserta kegiatan. Target luaran dari kegiatan pengabdian kepada masyarakat ini adalah artikel ilmiah yang telah di-submit dan akan dipublikasikan pada jurnal nasional tidak terakreditasi. Kesimpulannya bahwa kegiatan ini telah berhasil dilaksanakan dan manfaatnya dapat dirasakan langsung oleh para peserta. Hal ini dapat dilihat dari jawaban para peserta pada kuisioner yang diberikan setelah kegiatan dilaksanakan. Setelah kegiatan dilaksanakan, $88 \%$ peserta menjawab telah mengetahui materi yang disampaikan. Sarannya adalah sebaiknya kegiatan dengan tema ini dilaksanakan tidak hanya kepada masyarakat Kelurahan Rumbai Bukit, tetapi juga kepada masyarakat kelurahan-kelurahan lainnya yang ada di Kecamatan Rumbai Kota Pekanbaru.
\end{abstract}

Kata kunci: hukum, penyelesaian sengketa, agraria

\begin{abstract}
The problem of partners in community service activities is the lack of knowledge of the community of Rumbai Bukit Village, Rumbai District, Pekanbaru City regarding the settlement of disputes over land sale and purchase based on the Civil Code. The solution offered in this community service activity is to increase the knowledge of the community of Rumbai Bukit Village, Rumbai District, Pekanbaru City regarding the settlement of land purchase disputes based on the Civil Code. The implementation method used in community service activities is to use lecture, dialogue and discussion methods in order to provide legal counseling to the public. Partner participation in community service activities is to provide time, provide a place and supporting facilities, and present the community as participants of the activity. The output target of this community service is scientific articles that have been submitted and will be published in non-accredited national journals. The conclusion is that this activity has been successfully implemented and the benefits can be felt directly by the participants. This can be seen from the answers of the participants in the questionnaire given after the activity was carried out. After the activity was carried out, $88 \%$ of the participants answered that they knew the material presented. His suggestion is that the activities with this theme should be carried out not only to the people of Rumbai Bukit Village, but also to other urban communities in the Rumbai District of Pekanbaru City.
\end{abstract}

Keyword: law, dispute resolution, land 


\section{PENDAHULUAN}

Tanah adalah sumber daya alam yang terdiri atas bahan organik dan mineral sebagai pendukung kehidupan bagi makhluk hidup yang ada di atasnya, seperti manusia, hewan, dan tumbuhan. Makhluk hidup sebagian besar sangat menggantungkan hidupnya pada tanah dan unsur-unsur yang terkandung di dalamnya. Oleh karena itu, tanah merupakan sumber daya alam yang sangat penting keberadaannya, termasuk bagi masyarakat di Indonesia. Tanah sebagai karunia dan amanah dari Tuhan Yang Maha Esa yang dianugerahkan kepada bangsa Indonesia merupakan kekayaan sumber daya alam yang sangat berharga yang tidak ternilai harganya. Tanah merupakan salah satu modal utama dalam pembangunan nasional, sehingga harus dikelola dengan baik agar bermanfaat dalam rangka mewujudkan kesejahteraan masyarakat.

Undang-Undang Dasar Negara Republik Indonesia Tahun 1945 menegaskan bahwa bumi, air, dan kekayaan alam yang terkandung di dalamnya dikuasai oleh negara dan dipergunakan untuk sebesar-besar kemakmuran rakyat. Ketentuan tersebut diatur pada Pasal 33 Ayat (3) Undang-Undang Dasar Negara Republik Indonesia Tahun 1945. Kata 'bumi' yang terdapat dalam Pasal 33 Ayat (3) Undang-Undang Dasar Negara Republik Indonesia Tahun 1945 dapat ditafsirkan dan dipahami sebagai 'tanah'.

Dasar hukum yang mengatur mengenai tanah di Indonesia yaitu Undang-Undang Republik Indonesia Nomor 5 Tahun 1960 tentang Peraturan Dasar Pokok-pokok Agraria. Berdasarkan Pasal 2 Undang-Undang Republik Indonesia Nomor 5 Tahun 1960 tentang Peraturan Dasar Pokok-pokok Agraria dijelaskan bahwa pemerintah sebagai penyelenggara negara diberikan mandat oleh konstitusi untuk menguasai dan mengelola tanah dalam rangka mewujudkan kesejahteraan masyarakat, diberikan kewenangan untuk:

1. Mengatur dan menyelenggarakan peruntukan, penggunaan, persediaan, dan pemeliharaan bumi, air, dan ruang angkasa.

2. Menentukan dan mengatur hubungan-hubungan hukum antara orang-orang dengan bumi, air, dan ruang angkasa.

3. Menentukan dan mengatur hubungan-hubungan hukum antara orang-orang dan perbuatan-perbuatan hukum yang mengenai bumi, air, dan ruang angkasa.

Ketentuan yang terdapat pada Pasal 2 Undang-Undang Republik Indonesia Nomor 5 Tahun 1960 tentang Peraturan Dasar Pokok-pokok Agraria di atas, selain mengatur mengenai kewenangan pemerintah untuk mengelola sendiri tanah yang dikuasainya, juga mengatur mengenai kewenangan pemerintah untuk memberikan hak kepada masyarakat, baik secara individu maupun bersama-sama, serta badan-badan hukum untuk mengelola dan memanfaatkan tanah. Adapun bentuk-bentuk hak atas tanah yang diatur dalam Undang-Undang Republik Indonesia Nomor 5 Tahun 1960 tentang Peraturan Dasar Pokok-pokok Agraria antara lain yaitu Hak Milik, Hak Guna Usaha, Hak Guna Bangunan, Hak Pakai, Hak Sewa, Hak Membuka Tanah, Hak Memungut Hasil Hutan, dan lain sebagainya. Ketentuan tersebut terdapat pada Pasal 16 Ayat (1) Undang-Undang Republik Indonesia Nomor 5 Tahun 1960 tentang Peraturan Dasar Pokok-pokok Agraria.

Dalam rangka menjamin adanya kepastian hukum terhadap hak atas tanah, maka berdasarkan Pasal 19 Undang-Undang Republik Indonesia Nomor 5 Tahun 1960 tentang Peraturan Dasar Pokok-pokok Agraria disebutkan bahwa wajib dilakukan pendaftaran tanah, yang meliputi:

1. Pengukuran pemetaan dan pembukuan tanah.

2. Pendaftaran hak atas tanah dan peralihan hak tersebut.

3. Pemberian surat tanda bukti hak atas tanah yang berlaku sebagai alat pembuktian yang kuat. 
Dasar hukum yang mengatur mengenai pendaftaran tanah sebagai turunan dari Pasal 19 Undang-Undang Republik Indonesia Nomor 5 Tahun 1960 tentang Peraturan Dasar Pokok-pokok Agraria yaitu Peraturan Pemerintah Republik Indonesia Nomor 24 Tahun 1997 tentang Pendaftaran Tanah. Pada peraturan pemerintah tersebut dijelaskan bahwa pendaftaran tanah adalah rangkaian kegiatan yang dilakukan oleh pemerintah secara terus-menerus, berkesinambungan, dan teratur yang meliputi pengumpulan, pengolahan, pembukuan, dan penyajian serta pemeliharaan data fisik dan data yuridis dalam bentuk peta dan daftar mengenai bidang-bidang tanah, termasuk pemberian surat tanda bukti haknya bagi bidang-bidang tanah yang sudah ada haknya serta hak-hak tertentu yang membebaninya.

Pendaftaran tanah, selain bertujuan untuk memberikan kepastian hukum mengenai hak atas tanah, juga memberikan perlindungan hukum kepada pemegang hak atas tanah serta menjadi sumber informasi mengenai kepemilikan tanah dan peralihannya.

Khalayak sasaran pada kegiatan pengabdian kepada masyarakat ini adalah masyarakat Kelurahan Rumbai Bukit Kecamatan Rumbai Kota Pekanbaru. Dari observasi awal dan wawancara yang dilakukan dengan Ketua Lembaga Pemberdayaan Masyarakat (LPM) Kelurahan Rumbai Bukit, diketahui bahwa permasalahan yang sering dihadapi oleh masyarakat Kelurahan Rumbai Bukit adalah sengketa dalam jual beli tanah, terutama cara mengajukan gugatan ke pengadilan beserta alat-alat bukti yang harus dilampirkan apabila ditemukannya bukti kepemilikan ganda terhadap objek tanah yang sama. Oleh karena itu, perlu diadakannya penyuluhan hukum yang berjudul "Peningkatan Pengetahuan Masyarakat Kelurahan Rumbai Bukit Kecamatan Rumbai Kota Pekanbaru Mengenai Penyelesaian Sengketa Jual Beli Tanah Berdasarkan Kitab Undang-Undang Hukum Perdata”.

\section{METODE PELAKSANAAN}

Metode pelaksanaan dalam kegiatan pengabdian kepada masyarakat ini adalah dengan menggunakan metode ceramah, dialog, dan diskusi dalam rangka penyuluhan hukum tentang peningkatan pengetahuan masyarakat Kelurahan Rumbai Bukit Kecamatan Rumbai Kota Pekanbaru mengenai penyelesaian sengketa jual beli tanah berdasarkan Kitab Undang-Undang Hukum Perdata.

Metode pendekatan yang ditawarkan untuk menyelesaikan permasalahan mitra dalam kegiatan pengabdian kepada masyarakat ini adalah dengan melakukan observasi awal ke Kelurahan Rumbai Bukit Kecamatan Rumbai Kota Pekanbaru guna menggali beberapa informasi mengenai kondisi masyarakat. Setelah itu, melakukan wawancara dengan Ketua LPM Kelurahan Rumbai Bukit guna mencari tahu permasalahan yang sering dihadapi oleh masyarakat.

Partisipasi mitra dalam kegiatan pengabdian kepada masyarakat ini yaitu Ketua LPM Kelurahan Rumbai Bukit berkontribusi menyediakan waktu, menyediakan tempat beserta fasilitas pendukungnya, dan menghadirkan masyarakat sebagai peserta kegiatan.

Evaluasi pelaksanaan kegiatan pengabdian kepada masyarakat ini dilakukan dengan membagikan kuisioner sebelum dan sesudah kegiatan dilaksanakan untuk mengukur tingkat pengetahuan masyarakat. Keberhasilan pelaksanaan kegiatan pengabdian kepada masyarakat ini diukur dari antusias para peserta yang mengikuti kegiatan, adanya pertanyaan yang diajukan oleh para peserta, serta jawaban para peserta pada kuisioner yang telah dibagikan sebelum dan sesudah kegiatan dilaksanakan. 


\section{HASIL DAN PEMBAHASAN}

Kegiatan pengabdian kepada masyarakat ini dilaksanakan pada hari Kamis tanggal 20 Juni 2019 dimulai pukul 14.00 WIB sampai dengan selesai bertempat di aula Kantor Lurah Rumbai Bukit yang beralamat di Jl. Sri Indra, Rumbai. Kegiatan pengabdian kepada masyarakat ini dihadiri sebanyak 20 (dua puluh) orang peserta sebagaimana terlampir dalam daftar hadir. Pelaksanaan kegiatan pengabdian kepada masyarakat ini berjalan dengan lancar karena judul yang diangkat sesuai dengan permasalahan mitra dan kebutuhan para peserta.

Sikap khalayak sasaran selama pelaksanaan kegiatan pengabdian kepada masyarakat ini adalah baik dan antusias dalam memperhatikan materi yang dipaparkan oleh tim pelaksana. Hal ini didukung oleh Ketua LPM Kelurahan Rumbai Bukit Kecamatan Rumbai Kota Pekanbaru yang memfasilitasi kegiatan dengan menyediakan waktu, tempat, dan fasilitas pendukung lainnya.

Selain meningkatkan pengetahuan masyarakat Kelurahan Rumbai Bukit Kecamatan Rumbai Kota Pekanbaru mengenai penyelesaian sengketa jual beli tanah berdasarkan Kitab Undang-Undang Hukum Perdata, hasil fisik yang bermanfaat bagi para peserta adalah memperoleh materi yang diberikan oleh tim pelaksana dalam bentuk fotokopi hand out materi.

Untuk mengetahui sejauh mana tingkat pengetahuan para peserta mengenai materi yang akan disampaikan, maka sebelum pelaksanaan kegiatan, tim pelaksana membagikan kuisioner yang terdiri atas 5 (lima) pertanyaan untuk langsung diisi oleh para peserta. Selanjutnya, untuk mengetahui keberhasilan dari pelaksanaan kegiatan pengabdian kepada masyarakat ini, maka tim pelaksana kembali membagikan kuisioner yang terdiri atas 5 (lima) pertanyaan yang sama kepada para peserta setelah kegiatan dilaksanakan.

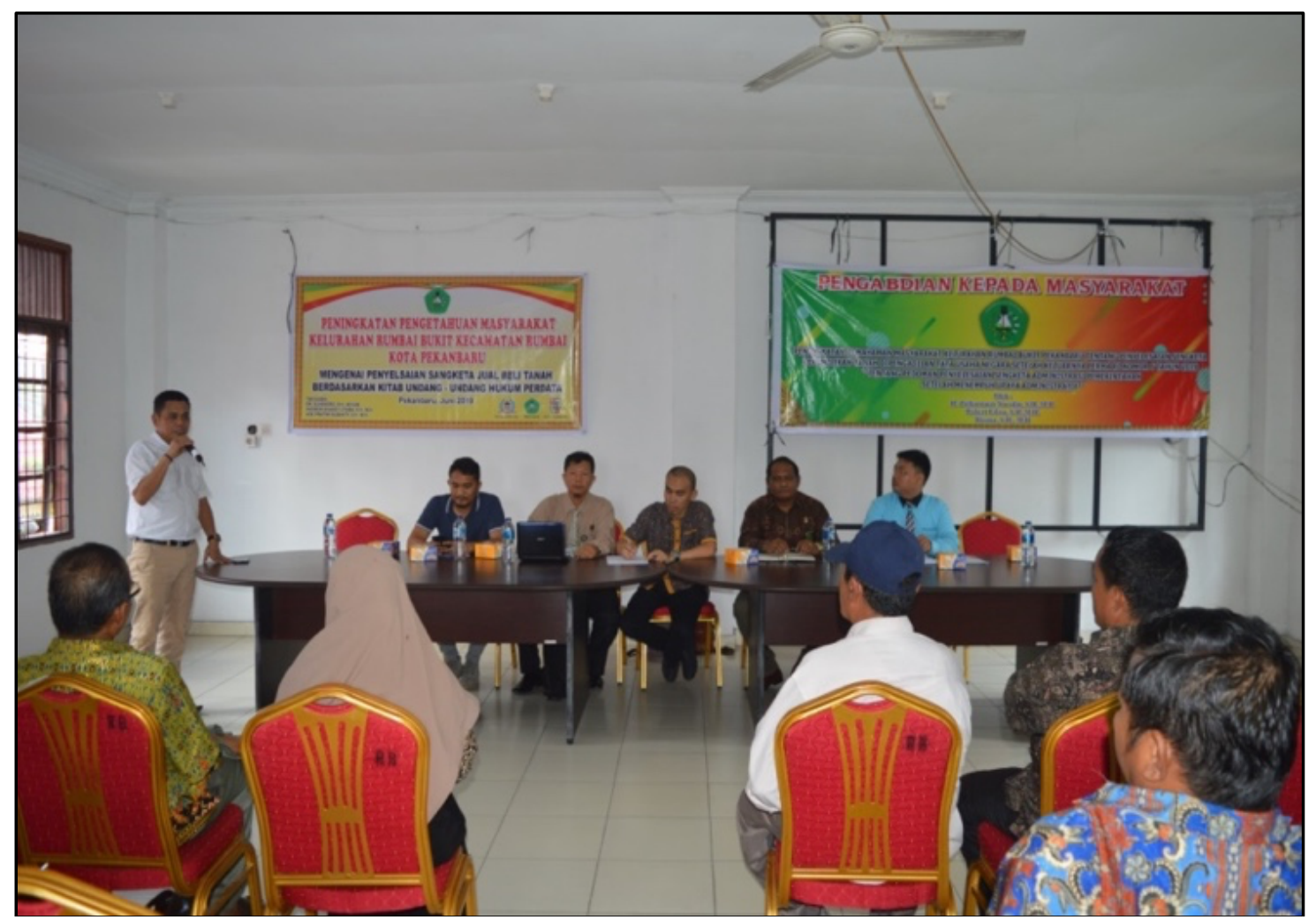

Gambar 1. Kata sambutan dari Ketua LPM Kelurahan Rumbai Bukit 


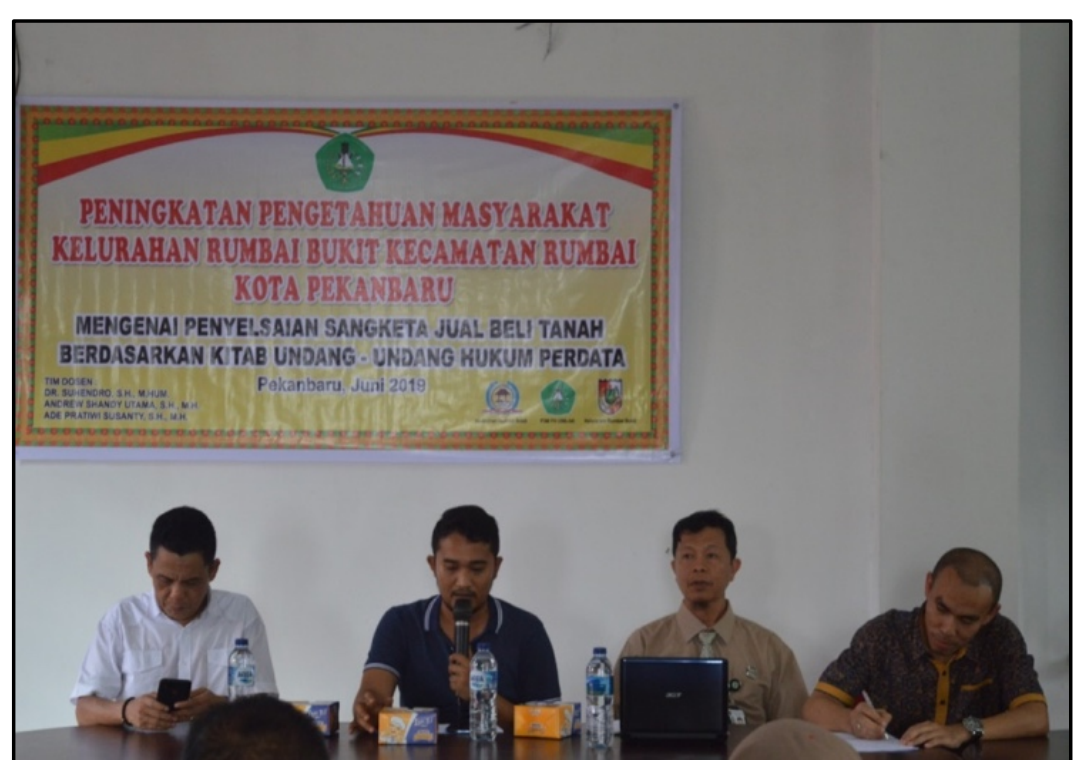

Gambar 2. Kata sambutan dari Lurah Rumbai Bukit

Pada kegiatan pengabdian kepada masyarakat ini, tim pelaksana yang terdiri atas Dr. Suhendro, S.H., M.Hum. sebagai ketua serta Andrew Shandy Utama, S.H., M.H. dan Ade Pratiwi Susanty, S.H., M.H. sebagai anggota memaparkan materi mengenai 'Penyelesaian Sengketa Jual Beli Tanah Berdasarkan Kitab Undang-Undang Hukum Perdata'.

Pelaksanaan kegiatan pengabdian kepada masyarakat ini dapat dikatakan telah berhasil dilaksanakan dan manfaatnya dapat dirasakan langsung oleh para peserta, yaitu meningkatkan pengetahuan masyarakat Kelurahan Rumbai Bukit Kecamatan Rumbai Kota Pekanbaru mengenai penyelesaian sengketa jual beli tanah berdasarkan Kitab Undang-Undang Hukum Perdata. Hal ini dapat dilihat dari jawaban para peserta pada kuisioner yang diberikan sebelum dan setelah kegiatan dilaksanakan. Sebelum kegiatan dilaksanakan, dari 20 orang peserta, hanya $6 \%$ yang menjawab telah mengetahui mengenai materi yang akan disampaikan. Sedangkan, setelah kegiatan dilaksanakan, 88\% peserta menjawab telah mengetahui materi yang disampaikan.

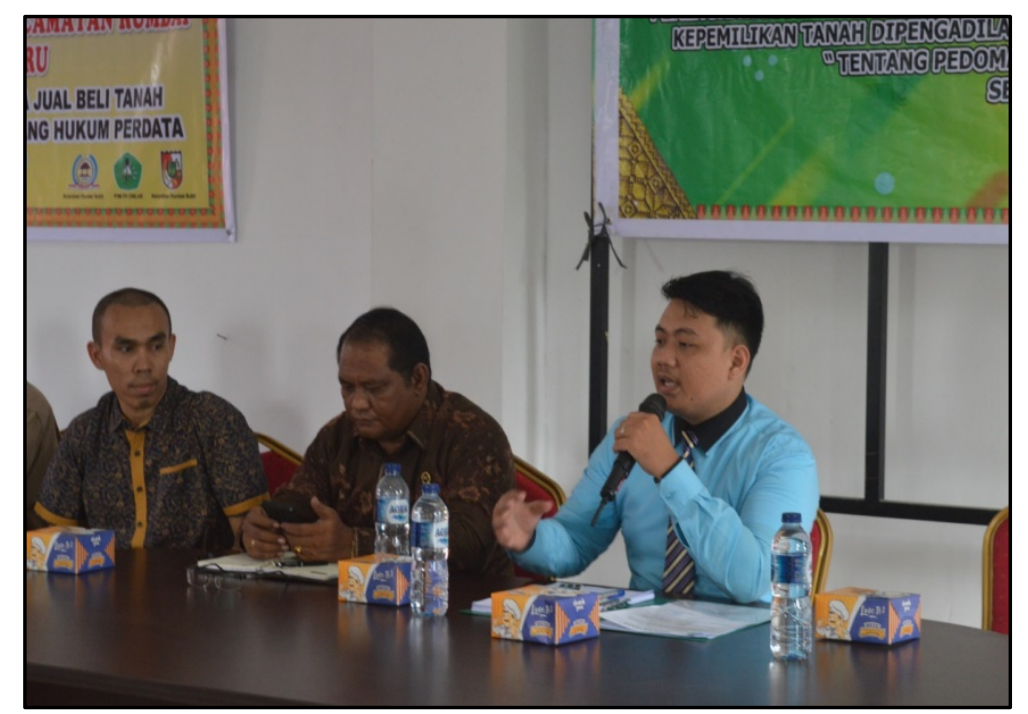

Gambar 3. Penyampaian materi oleh Andrew Shandy Utama, S.H., M.H. 


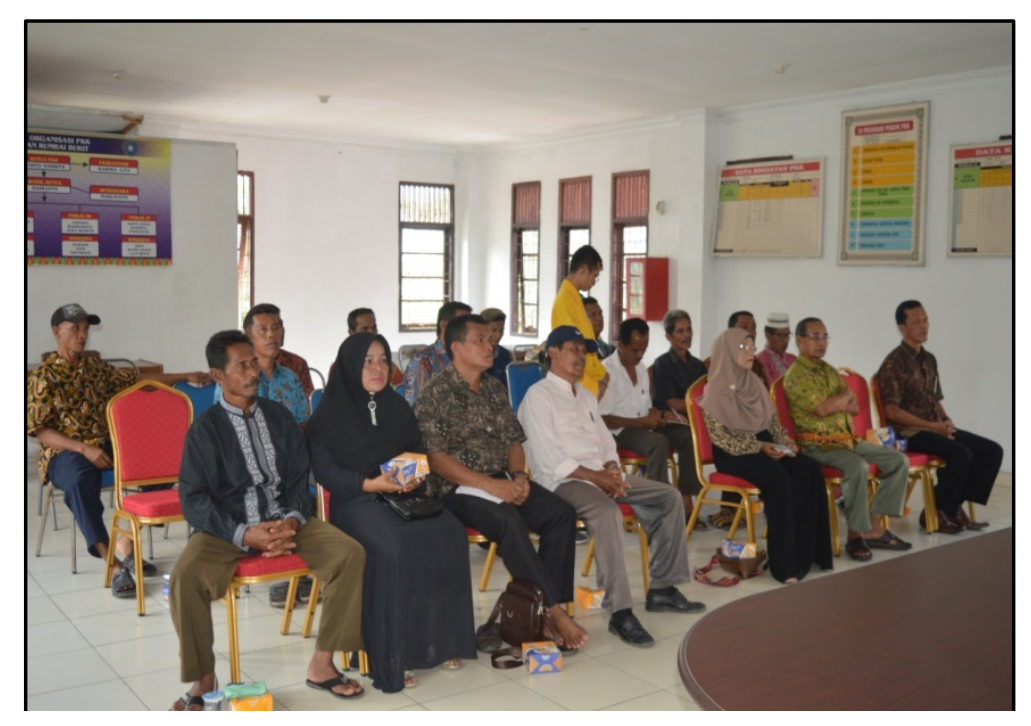

Gambar 4. Peserta kegiatan sedang memperhatikan materi yang disampaikan

Kegiatan pengabdian kepada masyarakat ini ditanggapi secara positif oleh para peserta. Tanggapan positif itu dapat dilihat dari adanya respon berupa pertanyaan dari salah seorang peserta setelah tim pelaksana memaparkan materi, yaitu peserta yang bernama Maswir mengajukan pertanyaan "Di Kelurahan Rumbai Bukit ini pernah saya menemukan ada salah seorang warga yang membeli tanah dan memiliki bukti kepemilikannya berupa SHM, lalu beberapa tahun kemudian juga ada seseorang yang mengaku memiliki tanah tersebut dan memiliki bukti kepemilikannya berupa SKGR yang diterbitkan jauh sebelum terbitnya SHM milik salah seorang warga tersebut. Apabila ditemukan adanya surat tanah yang berbeda nama pemiliknya tetapi di atas tanah yang sama, bagaimana cara menggugatnya ke pengadilan"

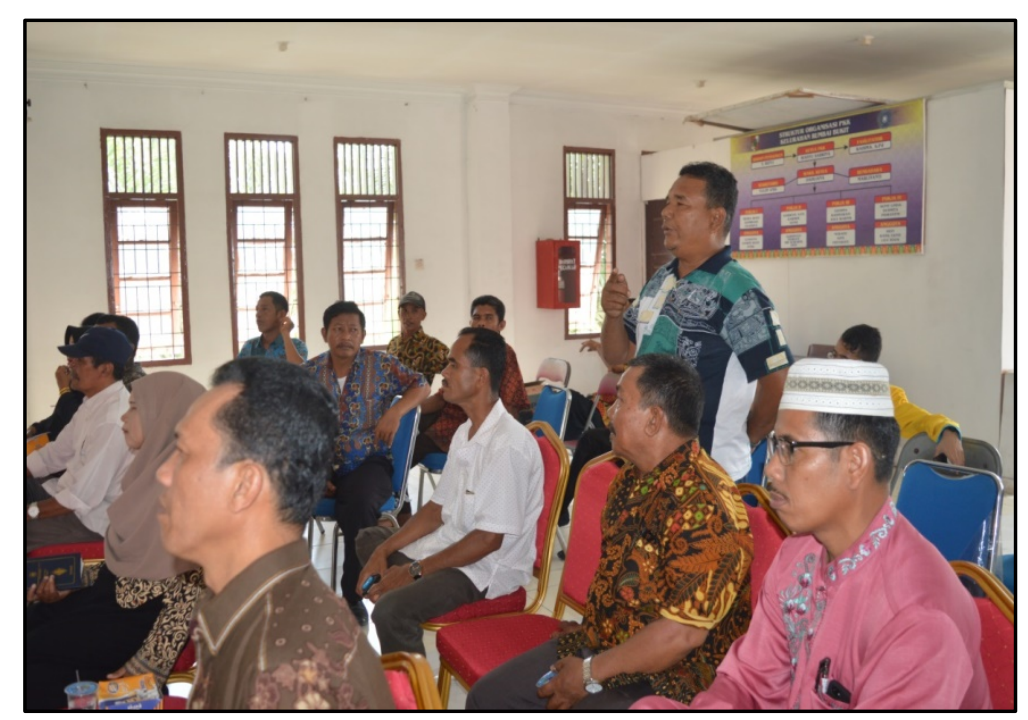

Gambar 5. Pertanyaan dari peserta yang bernama Maswir 
Berdasarkan Undang-Undang Republik Indonesia Nomor 5 Tahun 1960 tentang Peraturan Dasar Pokok-pokok Agraria disebutkan bahwa bentuk-bentuk hak atas tanah antara lain yaitu Hak Milik, Hak Guna Usaha, Hak Guna Bangunan, dan lain sebagainya.

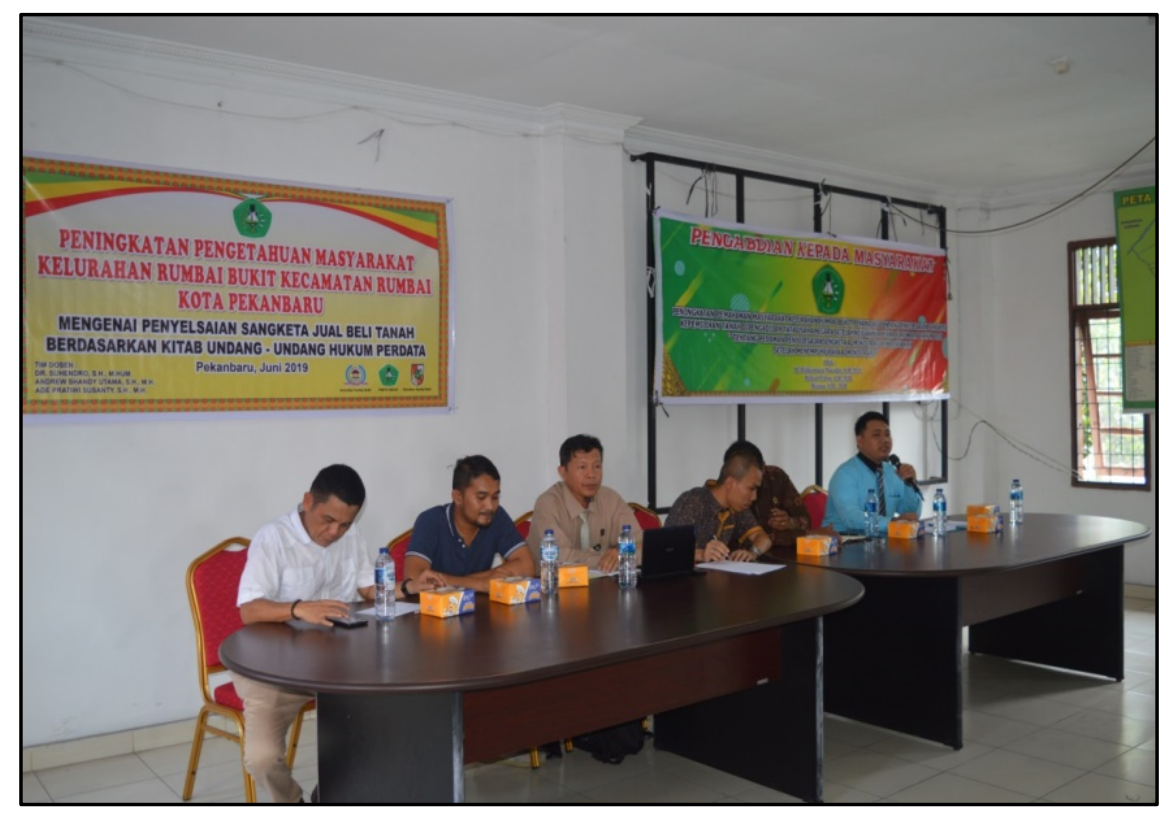

Gambar 6. Andrew Shandy Utama, S.H., M.H. menjawab pertanyaan dari peserta yang bernama Maswir

Hak Milik adalah hak turun-temurun, terkuat dan terpenuh yang dapat dipunyai orang atas tanah, yang dapat beralih dan dialihkan kepada pihak lain serta mempunyai fungsi sosial. Setelah melakukan pendaftaran tanah, maka pemegang Hak Milik akan menerima bukti kepemilikan tanah berupa Sertifikat Hak Milik (SHM), bukan Surat Keterangan Ganti Rugi (SKGR). SKGR merupakan surat yang menerangkan telah diberikannya ganti rugi karena adanya peralihan hak atas tanah yang dilakukan melalui kegiatan jual beli.

Perlu diketahui bahwa SHM belum tentu kedudukannya lebih kuat daripada SKGR. Apabila terhadap suatu objek tanah diterbitkan SHM, maka pihak yang merasa dirugikan, meskipun hanya memiliki SKGR, dapat mengajukan keberatan kepada pejabat yang berwenang, yaitu Badan Pertanahan Nasional Kota Pekanbaru. Badan Pertanahan Nasional Kota Pekanbaru kemudian akan memberikan jawaban atas keberatan yang diajukan tersebut. Apabila pihak yang merasa dirugikan tidak puas dengan jawaban dari Badan Pertanahan Nasional Kota Pekanbaru, maka pihak tersebut dapat mengajukan banding ke Badan Pertanahan Nasional Provinsi Riau. Apabila dalam 10 hari kerja belum ada jawaban, maka pihak yang merasa dirugikan dapat mengajukan gugatan ke Pengadilan Tata Usaha Negara untuk meminta dibatalkannya SHM tersebut.

Kegiatan penyuluhan hukum dengan judul "Peningkatan Pengetahuan Masyarakat Kelurahan Rumbai Bukit Kecamatan Rumbai Kota Pekanbaru Mengenai Penyelesaian Sengketa Jual Beli Tanah Berdasarkan Kitab Undang-Undang Hukum Perdata” ini merupakan salah satu bentuk pengabdian kepada masyarakat berupa penyuluhan hukum yang dilaksanakan oleh tim dosen dari Fakultas Hukum Universitas Lancang Kuning. 


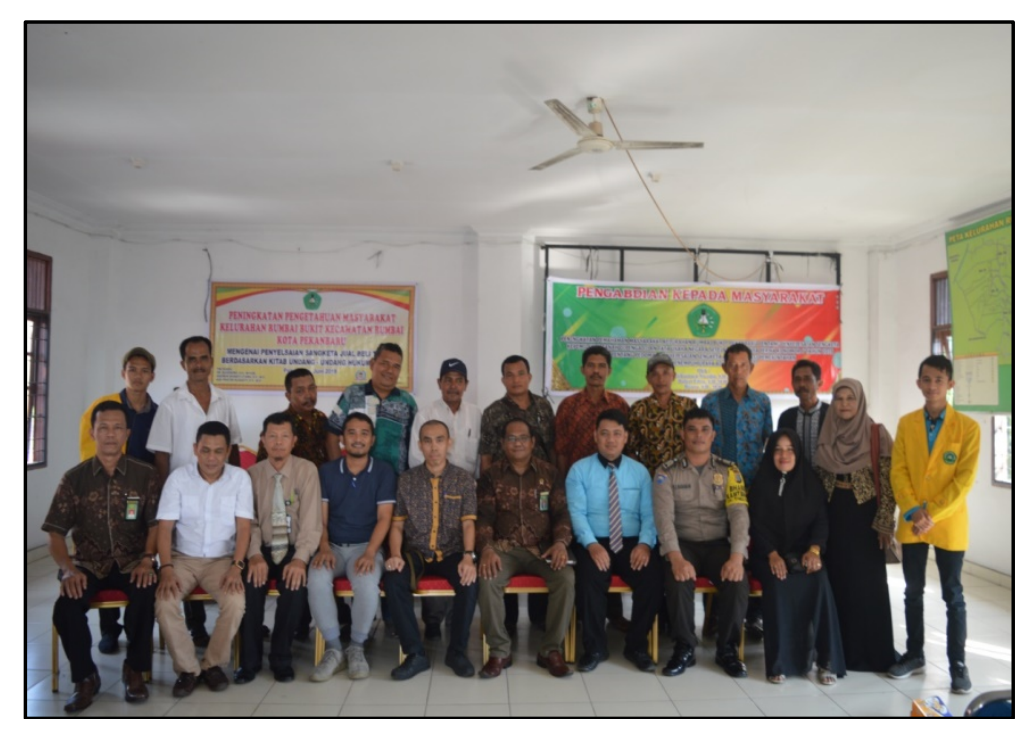

Gambar 6. Foto bersama antara pemateri, mitra, dan peserta kegiatan

\section{KESIMPULAN}

Permasalahan mitra dalam kegiatan pengabdian kepada masyarakat ini adalah minimnya pengetahuan masyarakat Kelurahan Rumbai Bukit Kecamatan Rumbai Kota Pekanbaru mengenai penyelesaian sengketa jual beli tanah berdasarkan Kitab UndangUndang Hukum Perdata. Pelaksanaan kegiatan pengabdian kepada masyarakat ini dapat dikatakan telah berhasil dilaksanakan dan manfaatnya dapat dirasakan langsung oleh para peserta, yaitu meningkatkan pengetahuan masyarakat Kelurahan Rumbai Bukit Kecamatan Rumbai Kota Pekanbaru mengenai penyelesaian sengketa jual beli tanah berdasarkan Kitab Undang-Undang Hukum Perdata. Hal ini dapat dilihat dari jawaban para peserta pada kuisioner yang diberikan sebelum dan setelah kegiatan dilaksanakan. Sebelum kegiatan dilaksanakan, dari 20 orang peserta, hanya $6 \%$ peserta yang menjawab mengetahui materi yang akan disampaikan. Sedangkan, setelah kegiatan dilaksanakan, $88 \%$ peserta menjawab telah memahami materi yang disampaikan.

Pengabdian kepada masyarakat dengan tema mengenai penyelesaian sengketa jual beli tanah ini penting untuk terus dilaksanakan karena merupakan permasalahan yang selalu dihadapi oleh masyarakat. Sebaiknya kegiatan dengan tema ini dilaksanakan tidak hanya kepada masyarakat Kelurahan Rumbai Bukit, tetapi juga kepada masyarakat kelurahan-kelurahan lainnya yang ada di Kecamatan Rumbai Kota Pekanbaru.

\section{DAFTAR PUSTAKA}

[1]. M. Arba, 2013, Hukum Agraria Indonesia, Jakarta: Sinar Grafika.

[2]. Frans Hendra Winarta, 2013, Hukum Penyelesaian Sengketa, Sinar Grafika, Jakarta.

[3]. Ratna Artha Windari, 2017, Pengantar Hukum Indonesia, Jakarta: Rajawali Pers.

[4]. Samun Ismaya, 2011, Pengantar Hukum Agraria, Yogyakarta: Graha Ilmu.

[5]. Takdir Rahmadi, 2010, Mediasi, Penyelesaian Sengketa Melalui Pendekatan Mufakat, Rajawali Pers, Jakarta.

[6]. Titik Triwulan Tutik, 2010, Hukum Perdata dalam Sistem Hukum Nasional, Kencana, Jakarta.

[7]. Urip Santoso, 2012, Hukum Agraria, Jakarta: Kencana Prenada Media. 